\title{
Angles
}

New Perspectives on the Anglophone World

$6 \mid 2018$

Experimental Art

\section{Contemporary British Art and its Contested Publicness: The Case of the Artangel Trust Experimenting with Site in Britain Today}

\section{Charlotte Gould}

\author{
(2) OpenEdition \\ 1 Journals \\ Electronic version \\ URL: https://journals.openedition.org/angles/1040 \\ DOI: 10.4000/angles. 1040 \\ ISSN: 2274-2042 \\ Publisher \\ Société des Anglicistes de l'Enseignement Supérieur
}

\section{Electronic reference}

Charlotte Gould, "Contemporary British Art and its Contested Publicness: The Case of the Artangel Trust Experimenting with Site in Britain Today", Angles [Online], 6 | 2018, Online since 01 April 2018, connection on 09 June 2022. URL: http://journals.openedition.org/angles/1040 ; DOI: https://doi.org/ 10.4000 /angles. 1040

This text was automatically generated on 9 June 2022

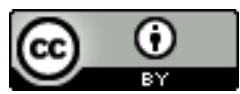

Angles est mise à disposition selon les termes de la Licence Creative Commons Attribution 4.0 International. 


\title{
Contemporary British Art and its Contested Publicness: The Case of the Artangel Trust Experimenting with Site in Britain Today
}

\author{
Charlotte Gould
}

1 The fairly recent reassessment of the value of British art means it has been possible to read some of its micro-histories as original and inventive rather than simply derivative of French or American art, especially early modern art. In this regard, Dana Arnold and David Peters Corbett's 2013 collection of essays A Companion to British Art, 1600 to the Present, appears as one of the latest attempts at reassessing the value of a national tradition which was long disparaged, even by English and British critics, for its supposedly misguided association with bourgeois patrons whose tastes were often decried as philistine. One of the chapters in the volume demonstrates how British modernism, for example, while it has often been considered as belated and undemonstrative, can today be appraised in a less universalist manner, and that in a more relativist period, it might be evaluated again, its author, Janet Wolff, going as far as to wonder whether realist or figurative art of the time - among which much of the productions of the Bloomsbury Group - might just as well be considered the art of modernity (Wolff 2013: 60-75). This type of reassessment which started in the second part of the $20^{\text {th }}$ century had to contend with centuries of aesthetic dismissal - which famously finds its roots in the iconoclasm which followed the English Reformation and the ingrained idea that artistic experimentation was not a British forte. It took the - short-lived - audacity of Pop in the 1960s, and then the brash confidence of Young British Artists in the 1990s to put an end to the country's artistic marginalisation and to allow its artists to showcase some of its idiosyncrasies as cutting-edge rather than parochial. This article will focus on recent trends in contemporary British art, particularly on the way in which specifically national attitudes to presenting, as well as to financing and commissioning works have opened up possibilities for the creation of 
ground-breaking art, thus disseminating experimental qualities over the whole process of imagining, producing and then remembering mostly ephemeral works.

The articulation of the experimental and the contemporary is not as obvious as one might assume, especially when art can return to painterly figuration, or to classical sculptural forms. In recent British art, the conjunction of the two seems to have manifested itself most strikingly in its occupation of sites outside of the museum or gallery, whether site-specific works or public art: from the monumentality of Antony Gormley's Angel of the North to the minute interventions of David Shrigley in the streets of Glasgow, as, for example, his hand-written note posted on a tree and which comically stated: "Lost: grey and white pidgeon (sic) with black bits. Normal size. A bit mangylooking. Does not have a name. Call 257 1964." Whether permanent or ephemeral, such interventions are described by Boris Groys as the momentary privatisation of public space through the act of installation. In these indeterminate shapes, Groys finds the expression of both an artistic and a curatorial freedom and says: "the artistic installation - in which the act of art production coincides with the act of its presentation - becomes the perfect experimental terrain for revealing and exploring the ambiguity that lies at the core of the Western notion of freedom." (Groys 2017) Recently, the experimental seems to have resided in the choice of new locations art has explored which, in a postmodern context in which the explicitly experimental avantgarde has waned as a concept, has allowed for situational, or contextual, rather than formal explorations. This of course tends to justify the national, territorial approach the present article is adopting. Recent debates about these new "territories" understood not just figuratively - explored by art have been particularly intense in Britain, especially in the texts of Claire Bishop or Jen Harvie, and have concerned new definitions of spectatorship, site-specificity, occupation of the public sphere and even of the delimitations between art and non-art - when a concert is both a concert and a performance, or when a swimming pool installed at King's Cross during construction work is both a functioning leisure equipment and an art work.

Over the last two or three decades, the publicness of British art seems to have been one of the most debated aspects of its contemporary manifestation, raising political and social questions as well as aesthetic ones. Art intended for public exhibition, and sometimes even more than that, art intended for social action and engineering, for regeneration and for community making - as opposed to the art created for the market, which also boomed in Britain over the same period, as exemplified by Damien Hirst's career - has been redefined formally and economically by the hybridisation of its public funding with private philanthropy and corporate sponsorship, thus resonating with contemporary redefinitions of how people understand notions of public and private today.

\section{The publicness of public art}

In his introduction to Art and the Public Sphere, W.J.T. Mitchell (1990) remarks that while studies of "public art" have traditionally been inquiries into the relation of beauty and bureaucracy, or studies of the art commissioned and owned by the State, new forms of publicness mean that today the question of spectatorship exists in the context of contested definitions of the public sphere - which, in The Structural Transformation of the Public Sphere. An Inquiry into a Category of Bourgeois Society, published in English in 
1989, Jürgen Habermas has described as a British invention. Publicness has indeed started to entail larger considerations which are not strictly spatial, but also political (will military drones gain access to our private properties?), economic (can public art be funded by sources other than the State?), social (we do tend to take our private phone conversations outside, for all to overhear), and technological (are online forums, accessed from the safety of our homes, the new public agora?). Mitchell designates publicity, surveillance and censorship as factors of transformation, and he is not overly pessimistic concerning the implications of these changing conditions on artistic possibilities:

What is the "public," for art or for anything else? Is there any such thing as a public sphere in the cultures of late capitalism? Are we witnessing the liquidation of the public sphere by publicity, the final destruction of the possibility of free public discussion, deliberation, and collective determination by a new culture of corporate, military, and state media management, and the emergence of a new world order in which public art will be the province of "spin doctors" and propagandists? Or does the internalization of global culture provide opportunities for new forms of public solidarity to emerge, and leave openings for the intrusion of new forms of public resistance to homogenization and domination? (Mitchell 1990:

2)

5 Public space is never fixed, it is always defined in context and according to how private space is envisaged at the same time, and to how privatisation imposes a reconfiguration of these definitions. What is sometimes presented as an actual genre, site-specific art, and which in the $20^{\text {th }}$ century was automatically associated with progressivity and criticality, is therefore in fact a rather ductile notion whose political efficiency has had to be reconfigured following the breakdown of traditional spatial experiences and the growing of a generic quality of sites, especially urban ones. Discussions of site-oriented art have been particularly interesting, abandoning the phenomenological mode of sitespecific art (for example, Richard Serra's "to remove the work is to destroy it" motto defending the grounded and fixed, even when it is ephemeral and singular), for a more discursive one. Miwon Kwon's 2000 article "The Wrong Place" observed a tendency to grant particular artistic validation to artists' nomadism, while also remarking on the standardisation of sites, of places made generic to accommodate capitalism via an abstraction of space (Kwon 2000: 33-43). Meanwhile, Simon Sheikh believes that the disappearance of the locality of the public sphere in the context of the globalism of high culture creates a "post-public situation" (Sheikh 2008: 35 and Robbins 1993) in which the public sphere has become spectral - sometimes more an object of nostalgia than an actual arena.

6 In her 2013 book Fair Play. Art Performance and Neoliberalism, Jen Harvie points to the ambiguities of today's art locations and how difficult it is for artists to escape being instrumentalised when, paradoxically, they try to escape the market forces at work in private galleries and even in some museums. She uses a commercial term to talk about today's ephemeral site-specific art: "pop-up venues," (Harvie 2013) a practice originating in times of economic recession when vacant properties are co-opted as temporary cultural spaces, an opportunistic harnessing of resources which gave rise to New York's Soho loft culture in the 1970s and has been associated with innovative art practices, but also, Harvie argues, with an acceptation of under-funding and the prospect that the interim artistic use will make the location attractive and result in more expensive real estate. The experimental character of site-specificity for its own sake, in this context, would merely be a historical, dated one. The "pop-up" space today 
still is an office, shop, or factory which is temporarily empty because it is not rented out, or awaiting renovation or demolition. It has the potential to become a temporary autonomous zone, or TAZ, as theorised by Hakim Bey. ${ }^{1}$ But when an increasingly high number of empty shops and estates are made available through the effects of the recession, their temporary use by artists saves owners costs on security, maintenance and business rates taxed on empty buildings, thus defeating its utopian occupation. Commenting on some recent uses made by artists of such empty locations, Harvie remarks that the political credentials they often assume derive directly from occupying disused or derelict buildings whose poverty has become an aesthetic feature, and that this automaticity must be questioned. She believes the sometimes professed ability of these contemporary works to enact social change simply because they are created within the community is compromised by risks of co-optation by a liberal agenda. The potential for such works to contribute to social inequalities through processes of gentrification, volunteerism and the naturalisation of economic exploitation is something Harvie is very critical of, as well as identifying an element of pastoral condescension for picturesque poor neighbourhoods in many contemporary works, something she found in Artangel commissions like Michael Landy's Break Down (2001) which took place in an empty C\&A shop on Oxford street, and, more tellingly, in Roger Hiorns' Seizure (2008) and the use it made of a derelict South London housing estate behind Elephant \& Castle.

In the heyday of Tony Blair's "Cool Britannia", art was indeed presented as a solution to increase employability, minimise crime and foster aspiration, but also, to regenerate deprived areas left impoverished by deindustrialisation. The Thatcher government had already been keen on the idea of regeneration because it was an American import, but it was New Labour who decided to invest more money in such schemes, bolstered until 2008 by favourable economic conditions, but also helped in great measure by the belated introduction of a National Lottery in Great Britain, which John Major approved in 1994, but which was going to benefit the cultural policy of New Labour when it came to power three years later. Artistic interventions outside of traditional institutions thus became a new major feature in Britain, supported by State money, but also by private funding which Margaret Thatcher had encouraged and New Labour did not renege on, and by Lottery money which is difficult to define as either strictly public - it is redistributed by the Treasury and then by the Arts Council - or private - it is a form of voluntary contribution by ticket buyers, even when they envisage it more as the possibility of coming into a huge sum than as a philanthropic act.

\section{Artangel commissions}

8 The Artangel Trust appears as a particularly useful case study to analyse how contemporary British art was still able to work around its contested publicness and the debates its political and financial context generated. Artangel have been credited with providing artists with all the money and logistics they need to bring their dream projects to life, and with finding ingenious ways of securing funding which does not tie them down with either the public or the private sector. An independent art commissioning agency based in London, it has operated since 1985 and is responsible for producing some of the most striking ephemeral and site-specific artworks in the last thirty years, from John Berger's Vertical Line, to Rachel Whiteread's House, or Alain 
Platel's Because I Sing. Artangel's existence spans three decades, which now form a consistent ensemble in terms of both art historical and political periodization. It was launched as a reaction to the cuts in funding for the visual arts and redirection towards private patrons introduced by the Thatcher government in 1979 and has since adapted in a distinctive way to changes in the government's and the Arts Council's cultural policies. Its mixed business model, the recourse to public, private and corporate funds, is indeed the result of the more general hybridisation of funding encouraged by consecutive governments since the 1980s. Their focus on scouting for unexpected locations to commission ephemeral works has earned them the esteem of the art world.

The question of site-specificity happens to have a particular British history. The process and issue-based type of work which emerged in the 1960s and 1970s had created new links with the public realm and allowed art to be defined as such outside of the gallery walls. In the United Kingdom, the Artist Placement Group founded in 1966 by John Latham and Barbara Steveni inaugurated a trend for artists' residencies, whether in businesses or in state administration, and their motto "the context is half the work" has become well-known. The 1977 Art in Public Places scheme then provided new incentives to take art outside. The ICA's seminal 1982 Art and Architecture conference later encouraged what came to be termed the "new collaboration" between artists, architects and planners on pioneering initiatives, namely the launch of the Art and Architecture Society in 1982, and, in 1984, of the Public Art Development Trust, supported by the Calouste Gulbenkian Foundation. Both organisations worked with the public and private sectors to encourage the commissioning of art in rural and urban settings, with the aim of involving artists in processes of regeneration. In 1986, Glasgow School of Art opened an Environmental Art Department with a public art remit. The arrival of Artangel in 1985, inspired by American models such as New York-based Creative Time (founded in 1973) or the Dia Art Foundation (1974), was framed by the same desire to escape the predictability of the gallery.

The trust has aimed to be experimental in the way it functioned as well as in the art it was going to help produce, its role being different from that played by the plethora of public art agencies and consultancies which the new cultural climate had fostered: indeed, Artangel never planned to act as a mediator between a client and an artist. The trust's directors since 1991, James Lingwood and Michael Morris, truly work alongside the artists they commission, with the planning of certain collaborations sometimes taking years, and can be considered to be the producers of the works, and not simply their commissioners.

\section{British cultural policies since the 1980s}

The 1980s had first seen a spectacular U-turn in British cultural policies from then on geared towards the encouragement of private support for the arts, with the introduction in 1984 of the Business Sponsorship Incentive Scheme (BSIS). By 1992-93, government expenditure of $£ 4.5$ million a year was producing sponsorship of $£ 7.5$ million a year. The 1990s and 2000s saw artists resist the promotion of culture as a tourist attraction by New Labour and the systematisation of the use of site-specific art for regenerative purposes. The 2010s were then marked by the cuts introduced by the coalition government in the face of which some independent art organisations like Artangel, preceded by ArtOffice or Locus+, soon followed by Situations, Modus 
Operandi, or InSite Art, were able to demonstrate that their hybrid model of financing in which Arts Council England money was now secured could allow them to weather such impositions. In 2011, ACE, the Heritage Lottery Fund and DCMS launched the $£ 100 \mathrm{~m}$ Catalyst scheme to boost private giving and endowments to arts organisations, something Artangel was actually able to benefit from. ${ }^{2}$

This post-consensus context, the political break with the Welfare State introduced by the Thatcher government in 1979, is one which has been marked by the growth in importance of the cultural sphere in Britain, both in terms of the positioning of the country's art market and in terms of public policy, although the successive governments in power since the 1980s have justified this new prominence differently. Art has either been transferred over to private interests in order to emulate an American model, or subsidised, but mostly because it was seen as an investment. The notion of "cultural industry" started becoming a motto in the early 1990s, with London all the while becoming defined as a new "creative city" (see Bianchini and Landry 1995). Cultural dynamism and artistic credentials became stakes in the competition between major cities as exemplified by the intense vying for the title of European City of Culture or for the yearly City of Culture badge. In an age when art and culture have been reassessed economically and politically, artists are often commissioned to obey policy directives and thus act as social workers capable of aiding society and of impacting urbanism. Andrew Hewitt has identified three claims made for the social function of art at the turn of the century: its role in cultural democracy, its function as an economic driver, the fact it offers solutions for social amelioration (Hewitt 2011: 19-36). These claims derive of course from a liberal tradition in the arts which believes they can help and improve the working class (Bennett 1998), but they are also mostly associated with the notion of culture-led regeneration. ${ }^{3}$ Hewitt admits that they are effective arguments to lever funding for the arts from the government, but he also sees the rhetoric as complicit with an agenda of marketisation and privatisation: "Cultural policy tied to this agenda produces the rhetoric of publicly funded art as a public good for social amelioration; the art it generates is hegemonic" (Hewitt 2011: 33). Indeed, the argument Hewitt opposes is that high culture might not be capable of such social engineering quite simply because it itself is actually what defines the traditional social division between the leisured elite and a working mass.

This British situation in which art, since the end of the 1980s, has become central to political debate, has been decried when art became a luxurious commodity (here the example of some very successful Young British Artists again comes to mind), but also when it made claims to social improvement (the efficiency of which is something Hewitt believes was never proven - while Claire Bishop has rather consistently bemoaned the consensual, almost drab, nature of so-called participatory or relational art (Bishop 2006)). Artangel have navigated through these debates and responded to cuts with works which offered to reclaim the public high street and London landmarks (Krzysztof Wodiczko's 1985 City Projection) and to highjack the tools of advertising for the purpose of political and social engagement (Barbara Kruger's We Don't Need Another Hero hoardings installed by the trust across England and Ireland, Les Levine's 1985 Blame God or Tim Head's 1986 International Contracts). They then responded to New Labour's instrumentalisation of art as part of the "Cool Britannia" rebranding of the country, and then to the coalition's call to self-reliance under the motto "Big society" by redefining site-specificity and ephemerality, and by confirming their taste for 
unusual locations, thus declining to produce politically and economically-efficient art to suit the current trends in cultural policy.

Artangel has not expressed a clear political opposition to changes in policy, at least not since the 1990s - its first steps were clearly taken to address the climate of the 1980s. The agency has however adopted a reactive position to either instrumentalisation or commercial exploitation through its choices of sites. As we have already stated, they have persistently sought out new locations for their projects by occupying disused estates, tube stations, cinemas, or buildings which bear the marks of the country's deindustrialisation, or by choosing lighter interventions which cannot be exploited for the purpose of regeneration. Because with Artangel projects, the choice of venue is as important as the medium or the technology used - their new slogan is "Extraordinary art, Unexpected places" - their distinctive appropriation of interim spaces in the city and outside, has come to resonate with the economic model they have had to shape for themselves in the particular British context. After having been very present in the high street and very visible in the 1980s and early 1990s through their use of the Spectacolour Screen on Picadilly Circus and of hoardings, Artangel today seem to seek out less visible locations. Their more discreet approach is probably a reaction to the age of political instrumentalisation exemplified by Tony Blair's March 6, 2007 speech at Tate Modern, with its focus on the economic benefits of an art boom the outgoing Prime Minister called a "golden age."

\section{Post-internet age}

The changing relations between art and its environment had also been further transformed from the end of 1980s by the development of the media. The new spaces explored by Artangel projects take into account the redefinitions political, social and technological changes have imposed on notions of public and private spaces, the gallery or museum themselves not necessarily embodying the opposite of the public sphere of the street. Indeed, the late $20^{\text {th }}$ century art gallery might sometimes be more immune to private interest than any other urban or rural site subject to planning or used for advertising, and the reintroduction by Tony Blair of free access in 2001 makes it a locus of sociability. By looking into projects based on walks through the city (Janet Cardiff's The Missing Voice in 1999), on radio or television broadcasts (Life Class: Today's Nude, Alan Kane's 2009 televised drawing class for Channel 4), on cinema theatres both as the apparatus for cinematic experiences and as sites where private emotions are dealt with publicly (Melanie Counsell's 1993 Coronet Cinema), one notices that reconfigurations of public and private realms are central to the way Artangel projects have explored new trends in site-specificity.

From the outset, Artangel have persistently sought out new locations for their projects which might redefine concepts of site-specificity - by making use of disused shops and buildings which bear the marks of the country's economic ups-and-downs, or by choosing lighter interventions which cannot be exploited for regeneration purposes. We have seen how Artangel have progressively sought out less visible locations, and how this might be down to their resistance to political instrumentalisation. Another explanation for this could be a reaction to the sudden prominence and visibility of Young British Art in the 1990s. More generally, the agency has approached space and 
site as a material in itself, a material susceptible to the transformations imposed by economic and political conditions.

In Situation Art, Claire Doherty explains how site-specificity has been replaced by situation-specificity, adding the notion of activity taking place at a specific place to the geographical and material location (Doherty 2004). Artangel are not looking into working with heritage or monuments in the traditional sense of the term, like the Fourth Plinth Project. Rather they choose places of circulation and favour the impermanence of the environment the artists are going to work with. Daniel Silvers' 2013 Dig took place in an open wound in the city of London, a disused parking lot which served as a blank, impermanent and unstable space, the exact opposite of a landmark. Its location close to the British Library but behind large palisades used to hide building sites hid it in plain view, the hustle and bustle of the area distracting from paying attention to the unexpected. A pretend archaeological site, it looked like an open wound in the city, which dug below the surface of a blank, impermanent space. Because Artangel commission works outside of the museum or gallery space, this means that their institutional recognition has to be all the stronger in order to confirm that this ephemeral event, this disruption in the cityscape is indeed an artwork. Even when Michael Landy occupied an empty C\&A store on Oxford Road for Break Down, its very central location was hidden by the fact that the space could still be mistaken for a shop.

The rapid commercialisation of the public sphere has been one of the causes for the redefinition of the boundaries between public and private sphere. Public and private divisions are dynamic because the privatisation of the public sphere through marketing is concurrent with the publicity given to private emotions, conversations or information in a society where communication is on the move thanks to mobile phones and widespread internet access. Public space is lent an aura of democracy in debates on urban design by a notion that it is where people of different classes, races, and genders mix informally. But British academic Malcolm Miles has also stressed the fact that, while it has today come to be defended in the face of the encroachment of privatised space in the Business Improvement Districts which are mushrooming in London, the shopping centre, and the gated compound, it was never a site of democracy, always a site in which power was performed by those who held it through processions, public executions, and the siting of public monuments which construct historical narratives to lend present regimes an illusion of being a logical culmination of a history (Miles 2008: 77). By neither indulging in a sort of National Heritage nostalgia nor in the picturesque of the ruin, but embracing both the past and the future, many Artangel projects have insisted on the inescapably mutable nature of public space.

Indeed, the very notion of context-specificity means that art works, the forms of which could have seemed dated, derivative, mere repetitions of modernist or $60 \mathrm{~s}$ and $70 \mathrm{~s}$ cutting-edge experimental works, are experimental still. In the relationship between site and work, new attempts at experimentation can be found. The ductility of locations itself, the fact that works no longer simply occupy a physical site but respond to a larger context which the location embodies, this imposes an experimental character to the art which is present there. The specific identity of the local has indeed experienced transformations, which make each site the locus both for itself and for the rest of the world. While architect Rem Koolhas has described the contemporary city as a "generic" one, one which has abandoned its specific identity to align with the impositions of global forces - commercial, political and even cultural - French geographer and 
anthropologist Michel Lussault has recently come up with the notion of hyper-lieux (hyperlocations), specific locations towards which people converge both physically and numerically, they are traversed by different experiences because they are places where things happen, which also happen online - for example Times Square in New York, or Notre-Dame-des-Landes in France where, from 2009 to 2018, protesters opposed the building of an airport in a ZAD (Zone à défendre). Site-specific works today encompass these conflicts between local and global forces, as well as technological connectivities, which shake the foundations of their sites. This unstable background is a marker of their contemporaneity.

\section{Conclusion}

Since the end of the 1980s, Artangel has managed to come up with a successful model which allows for all of these preoccupations to be taken into account. It has accompanied the development of "situation" art and helped redefine site-specificity for the turn of the century, it has suggested alternatives to the instrumentalisation of the "social turn" in art, as coined by Claire Bishop, and been at the forefront of a redefinition of ephemerality which is not simply an artwork with a set lifetime, but a work of art devised in a digital age. This successful venture confirms that the experimental is today not necessarily found in novel forms or styles, but also in novel ways of engaging with a transformed environment, and that this environment is a spatial one, but also, quite strikingly in Britain, an economic one.

Artangel has now become an influential beacon on the national artistic scene, and its sustained independence, its approach to locations, the ephemeral way it occupies them, has been inspirational for more established institutions, among them Tate Modern. Indeed, museums of contemporary art have today shed their traditional role as receptacles for approved, finished works, they are no longer mere custodians for posterity, but, inspired by examples such as that of Artangel, they have themselves become involved in the production of the works they show and in a discussion with the living artists who make them. On the heels of independent agencies like Artangel, of artist-run initiatives, or of the work done by a new generation of independent curators, museums now are themselves unusual locations for art interventions, and regularly function as laboratories, as official places traversed by artistic experimentations turning the Turbine Hall into a de-institutionalised public space open to passing artistic ideas.

\section{BIBLIOGRAPHY}

Arnold, Dana, and David Peters Corbett eds. A Companion to British Art, 1600 to the Present. Oxford: Blackwell, 2013.

Bennett, Tony. Culture, A Reformer's Science. London: Sage, 1998. 
Bey, Hakim. The Temporary Autonomous Zone, Ontological Anarchy, Poetic Terrorism (1985).

Weehawken: Grim Reaper Press, 1991. https://theanarchistlibrary.org/library/hakim-bey-t-a-zthe-temporary-autonomous-zone-ontological-anarchy-poetic-terrorism

Bianchini, Franco, and Charles Landry. The Creative City. London: Demos, 1995.

Bishop, Claire. Artificial Hells. Participatory Art and the Politics of Spectatorship. London: Verso, 2012.

Bishop, Claire. “The Social Turn: Collaboration and its Discontents," Artforum, February 2006: 178-183.

Blair, Tony. “Tony Blair's speech on the arts”, The Guardian, 6 March 2007. https:// www.theguardian.com/politics/2007/mar/06/politicsandthearts.uk1

Bourriaud, Nicolas. Esthétique relationnelle. Dijon: Presses du réel, 1998.

Connolly, Maeve. "Artangel and the Changing Mediascape of Public Art." Journal of Curatorial Studies 2 (2) 2013: 196-217. DOI: 10.1386/jcs.2.2.196_1

Doherty, Claire ed. From Studio to Situation. London: Black Dog Publishing, 2004.

Habermas, Jürgen. The Structural Transformation of the Public Sphere. An Inquiry into a Category of Bourgeois Society. Cambridge, Mass.: MIT, 1989.

Harvie, Jen. Fair Play. Art Performance and Neoliberalism. London: Palgrave Macmillan, 2013.

Hewitt, Andrew. “Privatizing the Public: Three rhetorics of art's public good in 'Third Way' cultural policy", Art \& the Public Sphere, Vol. 1 (1) 2011: 19-36. DOI: 10.1386/aps.1.1.19_1

King, Scott. Anish and Antony Take Afghanistan. Zurich: JRP Ringier, 2015.Koolhaas, Rem. The Generic City. New York: Monacelli, 1995.

Kwon, Miwon. “The Wrong Place”, Art Journal, Vol. 59, No. 1 (Spring, 2000): 33-43. DOI: 10.1080/00043249.2000.10791980

Lussault, Michel. Hyper-lieux. Paris: Seuil, 2017.

Miles, Malcolm. "Critical Spaces: Monuments and Changes", in Cameron Cartiere and Shelly Willis eds. The Practice of Public Art. London/ NY: Routledge, 2008. 66-90.

Mitchell, W.J.T. ed. "Introduction: Utopia and Critique" in Art and the Public Sphere. Chicago/ London: The U. of Chicago P., 1990. 1-5.

Robbins, Bruce ed. The Phantom Public Sphere. Minneapolis: Minneapolis UP, 1993.

Sheikh, Simon. "Publics and Post-publics. The Production of the Social," in: Jorinde Seijdel, ed. Art as a Public Issue: how art and its institutions reinvent the public dimension. Open, Rotterdam: NAi Publishers, 14 (2008). 28-36.

\section{NOTES}

1. Hakim Bey's (a pseudonym) “The Temporary Autonomous Zone, Ontological Anarchy, Poetic Terrorism" (1991, first published in 1985) is a famously anti-copyright text which can be accessed freely online, and in translation on a variety of platforms, and in which the author calls not for more public art, but for the more radical use of art sabotage. See, for instance, https:// theanarchistlibrary.org/library/hakim-bey-t-a-z-the-temporary-autonomous-zone-ontologicalanarchy-poetic-terrorism 
2. About the Catalyst programme aimed at helping arts organisations diversify their income by seeking out private support whether philanthropic or corporate, see the first Arts Council report published by the Arts Council in March 2014, http://www.artscouncil.org.uk/sites/default/files/ download-file/Catalyst\%20Evaluation\%20Year\%200ne\%20-\%20Final\%20Report.pdf last accessed July $9,2017$.

3. Artist Scott King's 2014 exhibition "De-regeneration" was a humorous take on public art and its endorsement by both western governments and "big business" alike for the sake of regeneration. The series Anish and Antony Take Afghanistan (King 2015) mocks the pretensions of the ideology of regeneration and its patronising gigantism in post-industrial Britain - as well as two British art stars. In A Balloon for Britain, 2012, King imagined that the Cameron government had offered him millions to devise a scheme to regenerate Britain's ten poorest towns and cities. The fictional result: an idea to float 50 metre tall party balloons across each of these poverty stricken areas.

4. An unabridged transcription of Tony Blair's speech can be found on the Guardian website (Blair 2007).

\section{ABSTRACTS}

The Artangel Trust, an independent art commissioning agency founded in London in 1985, is used as a case study to demonstrate how the experimental has come to be found in environmental explorations in Britain today, rather than in more strictly formal ones. Indeed, the curating and the siting of art, especially in a country whose artistic tradition has been defined by its insularity, has become the main locus of experimentations which touch upon creation, but also contextualisation and funding. The way art has recently escaped its institutional inscription has coincided, politically, with a post-Welfare encouragement of a new, specifically British funding model, combining a Continental form of State funding and money coming from philanthropic giving and corporate sponsorship, inspired by the cultural policy of the United States. This new economic context, coupled with a redefinition of the unusual public spaces these works occupy, point to the new conditions of artistic experimentation in Britain.

Le Artangel Trust, agence indépendante de commande d'œuvres publiques qui fut créée à Londres en 1985, est ici utilisé comme une étude de cas pour démontrer que l'expérimental se trouve aujourd'hui dans des explorations plus environnementales que formelles. En effet, le commissariat d'œuvres, et l'installation de celles-ci dans l'espace, en particulier dans un pays dont la tradition artistique a été définie en termes d'insularité, sont devenus les lieux principaux de l'expérimentation créative, expérimentation qui ne touche pas qu'à la forme, mais aussi à l'occupation de l'espace et aux conditions de financement. En effet, la façon dont l'art a souvent cherché ces derniers temps à échapper à son inscription institutionnelle a coïncidé, au RoyaumeUni, avec une rupture politique avec l'Etat-providence et avec la création d'un nouveau modèle national, associant un soutien d'État selon le modèle continental, et l'injection d'argent privé venant de mécènes et de sponsoring d'entreprise, inspiré par le modèle américain. Ce nouveau contexte, couplé à une nouvelle définition de ce qu'est l'espace public que ces œuvres occupent, se révèlent être les nouveaux terrains de l'expérimentation artistique britannique. 


\section{INDEX}

Keywords: public art, philanthropy, art commissioning, British cultural policy, United Kingdom, art

Mots-clés: art public, philanthropie, commande d'art, politiques culturelles britanniques, Royaume-Uni, art

\section{AUTHOR}

\section{CHARLOTTE GOULD}

Charlotte Gould is a former student of the École Normale Supérieure de Cachan and agrégée in English. Her doctoral thesis was defended at the Sorbonne Nouvelle in 2003 under the following title: "Les Young British Artists, L'École du scandale" and she is now Assistant professor in British culture and art at the Sorbonne Nouvelle (Paris 3), where she is a member of the research group 19-21. The focus of her research is contemporary British art, as well as public art commissioning since the 1980s. Recent publications include "Artangel Commissions, A New Approach to Site", in The International Journal of the Arts in Society (Common Ground, 2017), and the book chapter “Jeremy Deller's The Battle of Orgreave, rejouer 1984" in Ici notre défaite a commencé. La grève des mineurs britanniques (1984-1985) (Syllepse, 2016). In 2012, she co-directed the Ashgate volume Marketing Art in Britain: A Cultural History, 1700 to Today with Sophie Mesplède, which was reissued by Routledge as a paperback in 2017. She is a member of the Société des Anglicistes de l'Enseignement Supérieur (SAES), of the Association of Art Historians (AAH), and of The Arts in Society Research Network. Contact: c.gould[at]wanadoo.fr 